\title{
ПРИМЕНЕНИЕ МОДЕЛИ САМУЭЛЬСОНА-ХИКСА В УСЛОВИЯХ СОВРЕМЕННОЙ ЭКОНОМИКИ НА ПРИМЕРЕ БРАЗИЛИИ *
}

\author{
(c) 2021 Рощин Павел Андреевич \\ студент \\ Финансовый Университет при Правительстве РФ, Россия, Москва \\ E-mail:par.xxx@yandex.ru
}

(c) 2021 Трегуб Илона Владимировна

доктор экономических наук, профессор департамента математики

Финансовый университет при Правительстве Российской Федерации, Россия, Москва

E-mail: ilonavl_fa@mail.ru

В данной статье было проанализировано применение модели Самуэльсона-Хикса в Бразилии за период с 1975 по 2019 год. Анализ проводится в рамках рассмотрения взаимосвязи между валовым внутренним продуктом, инвестициями в нефинансовые активы, потреблением и валовые государственные расходы. Для анализа данных использовался регрессионный анализ, а для проверки адекватности - тесты Дарбина-Ватсона и Голдфельда-Квандта. Исследование проводится по нескольким направлениям: определение наличия гетероскедастичности, значимости модели, взаимосвязи между статистическими данными.

Ключевые слова: модель Самуэльсона-Хикса; модель бизнес-цикла; анализ данных; метод наименьших квадратов; прямые инвестиции, ВВП, регрессионный анализ.

Бразилия является 5-й по величине страной в мире и самой крупной страной в Южной Америке. Что касается экономики, Бразилия также является лидером Латинской Америки и занимает 9-е место в мире. На 2019 год оценочный ВВП страны составил 1,8 триллиона долларов.

Бразилия - гигант в области сельского хозяйства, горнодобывающей промышленности и производства. В течение долгого времени Бразилия является основным поставщиком кофе и соевых бобов, а также сахара, апельсинов и других сельскохозяйственных продуктов.

Бразилия является актуальной для изучения страной с точки зрения теории экономических циклов. Экономический бум в стране связывают с экспортом полезных ископаемых в 18 веке, кофе в 19 веке и каучука в конце 19 века. В общем, до 20 века все успехи бразильской экономики были связаны с сельским хозяйством. Идентифицировав зависимость экономики Бразилии от сельского хозяйства, правительство решило диверсифицировать экономику - с этого момента начался активный период урбанизации. В конце 19 века Бразилия развивала такие сферы, как горнодобывающая промышленность, гидроэнергетика и промышленность. После Великой депрессии 1930 года правительство взяло под свой контроль основные отрасли и крупнейшие компании. Тоталитарный контроль со стороны правительства подвергался резкой критике, однако он способствовал успеху многих из них. Основными инструментами Правительства были прямые инвестиции, налоги, пошлины и другие защитные меры. Задолго до этого были развиты такие отрасли, как судостроение, нефтехимия, производство персональных компьютеров и авиастроение. В течение периода 20-го века производство вносило наибольший вклад в ВВП, но позже его обогнал сектор услуг.

Следующим препятствием, с которым столкнулась бразильская экономика, стала инфляция. Высокие ставки коснулись всех секторов страны. Против этого Правительство реализовало «Реальный план», который включал приватизацию финансовых учреждений, производителей и горнодобывающих компаний. Сейчас перед бразильской экономикой стоят серьезные проблемы, возникшие из-за политической неопределенности. Безработица, отсутствие финансовой стабильностьии инфляция - главные проблемы государства в настоящее время.

Модель Самуэльсона-Хикса создана, чтобы

\footnotetext{
Текст статьи приведен на русском языке в сокращенном виде. Полный текст статьи доступен на английском языке на странице 315.
} 
показать, почему равенство совокупного предложения совокупному спросу достигается при разной степени использования производственных мощностей и трудовых ресурсов. Эта теория, наряду с теорией экономического роста, объясняет характер развития экономики во времени.

В реальной экономике предельная склонность к потреблению меньше единицы, а ускоритель больше единицы. При таких значениях предельной склонности к потреблению и ускорителю решение уравнения Хикса неустойчиво и носит колебательный характер: увеличение сменяется убывающим, убывающее - возрастающим. Это означает, что даже при постоянной норме инвестиций экономика нестабильна (как только баланс нарушается, он больше не восстанавливается), и периоды восстановления экономики чередуются с периодами спадов (кризисов). Именно поэтому данная модель может считаться актуальной для современных экономик, в том числе и для Бразилии.

В данной модели объединяются принцип ускорения и модель множителя. В основе принципа ускорения лежит теория, согласно которой незначительные изменения потребительского спроса могут вызвать значительные изменения инвестиционного спроса. В модели взаимодей- ствия валовой внутренний продукт (Y) зависит от трех групп расходов: инвестиций (I), потребления (C) и государственных расходов $(\mathrm{G})$.

Исходный набор данных включает данные с 1975 по 2019 год из открытых данных с официального сайта Всемирного банка и официального сайта статистики Бразилии.

Построим окончательную модель, включающую все линейные модели регрессии с учетом всех проведенных расчетов и тестов (1).

Итак, рассмотренная модель СамуэльсонаХикса позволяет сделать выводы о причинах и факторах возникновения эндогенных (самогенерирующих) циклических колебаний в экономической системе. В ходе анализа были определены ключевые переменные, которые оказывают значительное влияние на макроэкономические переменные, характеризующие бразильскую экономику. Модель Самуэльсона-Хикса справедливо описывает экономическую ситуацию в Бразилии. На основании проведенного анализа и полученных результатов можно утверждать, что модель бизнес-цикла Самуэльсона-Хикса соответствует ее реалиям. Этот факт был доказан тестами Дарбина-Ватсона и Голдфилда-Кванта, которые доказывают теорему Гаусса-Маркова.

$$
\left\{\begin{array}{c}
C_{t}=39.4208+0.8034 \cdot Y_{t-1}+u_{t} \\
I_{t}=-24.3392+3.3323 \cdot R_{t-1}-0.0114 \cdot Y_{t}+0.0525 \cdot Y_{t-1}+v_{t}, \\
G_{t}=10.9105+0,9835 \cdot G_{t-1}+w_{t} \\
Y_{t}=98.5796+0.6769 \cdot Y_{t-1}-0.2446 \cdot Y_{t-2}+2.6628 \cdot G_{t-1}+r_{t}
\end{array}\right.
$$

\section{Библиографический список}

1. Барруэко Э., Трегуб И. В. Эмпирическая проверка гипотетической модели экономики Германии / Современная наука. 2019. № 3. С. 36-41.

2. Данные национальных счетов Всемирного банка [Электронный ресурс] - URL: https://data.worldbank.org/ (дата обращения: 01.02.2021)

3. Прангишвили А. И., ОбгадзеЛ.Т. Математическое моделирование экономических циклов и оптимальное управление капитальными вложениями // Информатика и телекоммуникации. 2005 № 3 (7). с: 59-61.

4. Самуэльсон П. А. Взаимодействие мультипликативного анализа и принципа ускорения // Обзор экономической статистики. 1939, № 4 с .: 75-78.

5. Трегуб И. В. Математические модели динамики экономических систем: монография-М .: РУСАИНС, 2018.$164 \mathrm{c}$.

6. Трегуб И. В. Эконометрика на английском языке. Учебник. Москва: 2017

7. Трегуб И. В. Эконометрика. Модель реальной системы. Москва: 2016.164 с.

8. Трегуб И.В.Эконометрические исследования. Практические примеры. Эконометрические исследования. Практические примеры.- М: Лань, 2017. 164 с.

9. Трегуб И.В.Эконометрический анализ влияния денежно-кредитной политики на макроэкономические агрегаты в экономике Индии // Физический журнал: Серия конференций. 8. Сер. «2018 8-я Международная конференция по прикладной физике и математике, ICAPM 2018 » 2018. 


\title{
APPLICATION OF THE SAMUELSON-HICKS MODEL IN THE CONDITIONS OF MODERN ECONOMY BY EXAMPLE OF BRAZIL
}

\author{
(C) 2021 Roshchin Pavel Andreevich \\ Student \\ Financial University under the Government of the Russian Federation, Moscow, Russia \\ E-mail: par.xxx@yandex.ru \\ (c) 2021 Tregub Ilona Vladimirovna \\ Doctor of Economics, Professor of the Department of Mathematics \\ Financial university under the Government of the Russian Federation, Moscow, Russia \\ E-mail: ilonavl_fa@mail.ru
}

In this paper application of Samuelson-Hicks model in Brazil was analyzed from 1975 to 2019. The relationship between gross domestic product, investments in non-financial assets, consumption and gross government spending was examined. The Darbin-Watson test and the Goldfeld-Quandt test were used to check the model's adequacy. The study is conducted in several areas: determining the presence of heteroskedasticity and the significance of the model and the relationship between statistical data, identifying positive or negative correlations.

Keywords: Samuelson-Hicks model, business cycle model, data analysis, least square method, direct investment, regression model, GDP.

Brazil or officially Portuguese República Federativa do Brasil is the 5th largest country around the world and the hugest one in south America. As for economy - Brazil is also the leader of Latin America and 9th around the world. For 2019 estimated GDP of a country is 1,8 trillion \$.

Brazil is agriculture, mining and manufacturing giant. For the long time Brazil is a primary source of coffee and soy beans as well as of sugar, oranges and other agricultural products. With increased urbanization in country the service sector made a strong and rapid breakthrough as well.

Brazil is a great country to study the theory of economic cycles. The economic booms in the country are associated with export of minerals in 18 centuries, coffee in 19 century and rubber in the late 19 century. All in all, before 20 century all the success of Brazilian economy was connected with agriculture. After understanding dependence of Brazilian economy on agriculture, the government decided to diversify the economy and exploit some other industries. Since then an active period of urbanization started. In the late nineteenth Brazil developed spheres like mining, hydroelectric and industrial. After that following the great depression in 1930 government took control over main industries and largest companies. The government totalitarian control was criticized heavily, however it contributed to success of some of them. The main instruments of government were direct investments, taxes, duties and other protective measures. Back than industries like shipbuilding, petrochemical, personal computer and aircraft were developed. For the period during 20th century manufacturing contributed the most to GDP but later on it was overtaken by service sector.

The next obstacle faced by Brazilian economy became inflation. High rates affected every sector of the country. Against that government implemented the Real Plan which included privatization of financial institutions, manufacturers and mining companies. As for the modern days Brazilian economy facing serious problems raised due to political uncertainties. Unemployment, financial stability and inflation are main headaches of the government nowadays.

The Samuelson-Hicks model is produced to show why the equality of aggregate supply to aggregate demand is achieved with different degrees of utilization of production capacity and labor resources [7]. The theory, along with the theory of economic growth, explains the nature of the development of the economy over time.

In the real economy, the marginal propensity to consume is less than one, and the accelerator is greater than one. At such values of the marginal 
propensity to consume and the accelerator, the solution of the Hicks equation is unstable and has an oscillatory character: increasing is replaced by decreasing, decreasing-increasing. This means that even with a constant rate of investment, the economy is unstable (once the balance is broken, it is no longer restored), and periods of economic recovery alternate with periods of recessions (crises). That is why, from our point of view, this model can be considered as actual for modern economies because now the world economy is in crisis.

In this paper a Samuelson-Hicks model was analyzed. Samuelson combined acceleration principle and the multiplier model [5]. In the base of the acceleration principle laid the theory that insignificant changes in the consumer's demand can generate significant changes in the investment's demand. In the interaction model, the gross domestic product $(\mathrm{Y})$ is dependent on three expenditure groups: investment (I), consumption $(\mathrm{C})$ and government expenditure $(\mathrm{G})$.

In the interaction model, the gross domestic product $(\mathrm{Y})$ is dependent on three expenditure groups: investment (I), consumption (C) and government expenditure $(\mathrm{G})$. The main provisions of this theory are the interdependence of variables which allows to formulate the system of equations:

$$
\left\{\begin{array}{c}
\mathrm{C}_{\mathrm{t}}=\mathrm{a}_{0}+\mathrm{a}_{1} \mathrm{Y}_{\mathrm{t}-1}+\mathrm{u}_{\mathrm{t}} \\
\mathrm{I}_{\mathrm{t}}=\mathrm{a}_{2}+\mathrm{a}_{3}\left(\mathrm{Y}_{\mathrm{t}-1}-\mathrm{Y}_{\mathrm{t}-2}\right)+\mathrm{v}_{\mathrm{t}} \\
\mathrm{G}_{\mathrm{t}}=\mathrm{a}_{4} \mathrm{G}_{\mathrm{t}-1}+\mathrm{w}_{\mathrm{t}} \\
\mathrm{Y}_{\mathrm{t}}=\mathrm{C}_{\mathrm{t}}+\mathrm{I}_{\mathrm{t}}+\mathrm{G}_{\mathrm{t}} \\
\mathrm{E}\left(\mathrm{u}_{\mathrm{t}}\right)=0, \mathrm{E}\left(\mathrm{v}_{\mathrm{t}}\right)=0, \mathrm{E}\left(\mathrm{w}_{\mathrm{t}}\right)=0 \\
\sigma\left(\mathrm{u}_{\mathrm{t}}\right)=\text { const, } \sigma\left(\mathrm{v}_{\mathrm{t}}\right)=\text { const, } \sigma\left(\mathrm{w}_{\mathrm{t}}\right)=\text { const }
\end{array}\right.
$$

Where:

C - Private Consumption expenditure spent by residents or organization which serve households on consumption of goods and services.

I-Investments in Non-Financial Assets - the value of acquisitions of new or existing fixed assets by the business sector less disposals of fixed assets.

G - Government Expenditure - expenditures on goods and services which are used for the satisfaction of needs of individual consumption or collective needs of members of community.

Y - Gross Domestic Product - total amount of money which measure the total production of goods and services on the territory of a by residents and non-residents during the year.

$u_{t}, v_{t}, w_{t}$ are disturbance terms.

To use this system of equations to build a regression model, we transform it so that all the independent variables are on the left side.

$$
\left\{\begin{array}{c}
\mathrm{C}_{\mathrm{t}}=\mathrm{a}_{0}+\mathrm{a}_{1} \mathrm{Y}_{\mathrm{t}-1}+\mathrm{u}_{\mathrm{t}} \\
\mathrm{I}_{\mathrm{t}}=\mathrm{a}_{2}+\mathrm{a}_{3}\left(\mathrm{Y}_{\mathrm{t}-1}-\mathrm{Y}_{\mathrm{t}-2}\right)+\mathrm{v}_{\mathrm{t}} \\
\mathrm{G}_{\mathrm{t}}=\mathrm{a}_{4} \mathrm{G}_{\mathrm{t}-1}+\mathrm{w}_{\mathrm{t}} \\
\mathrm{Y}_{\mathrm{t}}=\mathrm{a}_{5}+\mathrm{a}_{6} \mathrm{Y}_{\mathrm{t}-1}+\mathrm{a}_{7} \mathrm{Y}_{\mathrm{t}-2}+\mathrm{a}_{8} \mathrm{G}_{\mathrm{t}-1}+\mathrm{r}_{\mathrm{t}}
\end{array}\right.
$$

The initial data set includes data from 1975 to 2019 from open data from the official World Bank website and the official statistics website of Brazil. According to the following indicators GDP (bln. current LCU, Y), Final consumption expenditure (bln. current LCU, C), Foreign direct investment, net inflows (bln. current LCU, I), General government final consumption expenditure (bln. current LCU, $\mathrm{G})$. All the data is shown in the table 1 .

Based on the presented in table 1 we constructed dependence of variables from time graphically. On the picture 1 we can see the strength dependence of indicators. For all variables, except the interest rate, we can note similar behavior.

As you can see on the chart, Brazil did not react much to the crisis of 200-2009. This is due to the fact that it is one of the last to enter a phase of decline both on the world stage and among the BRICS countries. The reason for this was the implementation of the program for investing in road, social and urban infrastructure, energy and production of the country, which was planned before the crisis. As a result, the volume of investments exceeded the planned level. Such measures have created additional jobs and mitigated the impact of the crisis on the economy.

The crisis in Brazil in 2011 is primarily related to the unstable domestic political situation. The population did not accept the current ruler, who in turn could not formulate the doctrine of foreign policy.

From the correlation matrix we also can admit the strong dependence within variables except the interest rate. All correlations coefficients are more than 0,9 that shows a positive direct relationship between the indicators that are used in the model.

However, the interest rate doesn't correlate with another variables. So we can expect that this parameter will not satisfy the conditions GaussMarkov theorem.

Based on the least squares method, a linear regression models were constructed for the four equations of the system [6]. 
Table 1. Initial data set [2]

\begin{tabular}{|c|c|c|c|c|c|c|}
\hline Year & $\begin{array}{c}\text { Y, GDP } \\
\text { (current bln. } \\
\text { US\$) }\end{array}$ & $\begin{array}{c}\text { T, Tax revenue } \\
\text { (current bln. } \\
\text { US\$) }\end{array}$ & $\begin{array}{c}\mathrm{R}, \text { Real } \\
\text { interest rate } \\
(\%)\end{array}$ & $\begin{array}{l}\text { G, General } \\
\text { government } \\
\text { spending } \\
\text { (current bln. } \\
\text { US\$) }\end{array}$ & $\begin{array}{c}\text { I, Foreign } \\
\text { direct } \\
\text { investment, } \\
\text { net inflows } \\
\text { (current bln. } \\
\text { US\$) }\end{array}$ & $\begin{array}{c}\text { C, Final } \\
\text { consumption } \\
\text { expenditure } \\
\text { (current bln. } \\
\text { US\$) }\end{array}$ \\
\hline 1975 & 123,71 & 17,32 & 6,33 & 13,16 & 1,21 & 95,41 \\
\hline 1976 & 152,68 & 21,37 & 6,01 & 16,06 & 1,30 & 121,04 \\
\hline 1977 & 176,17 & 34,53 & 5,71 & 16,62 & 1,56 & 138,46 \\
\hline 1978 & 200,80 & 28,11 & 5,43 & 19,39 & 1,83 & 157,06 \\
\hline 1979 & 224,97 & 31,50 & 5,15 & 21,91 & 2,01 & 178,37 \\
\hline 1980 & 235,02 & 29,15 & 4,90 & 21,62 & 2,42 & 185,45 \\
\hline 1981 & 263,56 & 27,37 & 4,65 & 24,56 & 1,91 & 203,72 \\
\hline 1982 & 281,68 & 39,44 & 4,42 & 28,18 & 2,52 & 224,14 \\
\hline 1983 & 203,30 & 28,46 & 4,20 & 19,64 & 2,91 & 164,48 \\
\hline 1984 & 209,02 & 45,21 & 3,99 & 17,32 & 1,61 & 164,37 \\
\hline 1985 & 222,94 & 31,21 & 3,79 & 22,00 & 1,59 & 168,65 \\
\hline 1986 & 268,14 & 37,54 & 3,60 & 28,62 & 1,44 & 210,34 \\
\hline 1987 & 294,08 & 33,82 & 3,42 & 35,77 & 0,35 & 218,88 \\
\hline 1988 & 330,40 & 46,26 & 3,25 & 41,60 & 1,17 & 238,17 \\
\hline 1989 & 425,60 & 59,58 & 3,09 & 65,96 & 2,80 & 296,34 \\
\hline 1990 & 461,95 & 64,67 & 2,93 & 89,12 & 1,13 & 363,08 \\
\hline 1991 & 602,86 & 84,40 & 2,78 & 107,91 & 0,99 & 479,08 \\
\hline 1992 & 400,60 & 75,26 & 2,65 & 68,35 & 1,10 & 314,80 \\
\hline 1993 & 437,80 & 61,29 & 2,51 & 77,33 & 2,06 & 340,37 \\
\hline 1994 & 558,11 & 78,14 & 2,39 & 88,36 & 1,29 & 429,80 \\
\hline 1995 & 769,31 & 107,70 & 2,27 & 161,00 & 3,07 & 651,10 \\
\hline 1996 & 850,43 & 119,06 & 2,15 & 167,97 & 4,86 & 722,08 \\
\hline 1997 & 883,20 & 117,24 & 6,54 & 172,54 & 12,55 & 749,35 \\
\hline 1998 & 863,72 & 120,92 & 7,76 & 173,35 & 19,65 & 727,37 \\
\hline 1999 & 599,39 & 83,91 & 6,71 & 118,58 & 31,91 & 506,26 \\
\hline 2000 & 655,42 & 91,76 & 4,85 & 123,01 & 28,38 & 546,36 \\
\hline 2001 & 559,37 & 78,31 & 4,56 & 108,20 & 32,99 & 466,80 \\
\hline 2002 & 507,96 & 71,11 & 4,83 & 100,63 & 23,23 & 415,05 \\
\hline 2003 & 558,32 & 78,16 & 4,64 & 106,51 & 16,59 & 451,80 \\
\hline 2004 & 669,32 & 75,24 & 4,38 & 123,61 & 10,12 & 526,58 \\
\hline 2005 & 891,63 & 124,83 & 4,46 & 168,43 & 18,18 & 707,90 \\
\hline 2006 & 1107,64 & 155,07 & 4,12 & 210,88 & 15,46 & 880,31 \\
\hline 2007 & 1397,08 & 195,59 & 3,50 & 264,65 & 19,38 & 1101,15 \\
\hline 2008 & 1695,82 & 237,42 & 3,54 & 319,48 & 44,58 & 1332,41 \\
\hline 2009 & 1667,02 & 241,26 & 3,48 & 327,58 & 50,72 & 1360,41 \\
\hline 2010 & 2208,87 & 309,24 & 2,91 & 420,06 & 31,48 & 1750,30 \\
\hline 2011 & 2616,20 & 366,27 & 3,28 & 488,43 & 82,39 & 2065,31 \\
\hline 2012 & 2465,19 & 345,13 & 2,66 & 456,80 & 102,43 & 1970,72 \\
\hline 2013 & 2472,81 & 346,19 & 1,85 & 467,17 & 92,57 & 1993,27 \\
\hline 2014 & 2455,99 & 343,84 & 2,24 & 470,41 & 75,21 & 2016,69 \\
\hline 2015 & 1802,21 & 252,31 & 3,38 & 356,42 & 87,71 & 1509,20 \\
\hline 2016 & 1795,70 & 251,40 & 4,07 & 365,95 & 64,74 & 1519,72 \\
\hline 2017 & 2062,83 & 245,23 & 4,18 & 416,04 & 74,29 & 1746,21 \\
\hline 2018 & 1885,48 & 263,97 & 3,47 & 378,70 & 68,89 & 1598,68 \\
\hline 2019 & 1839,76 & 257,57 & 3,20 & 373,15 & 78,16 & 1567,82 \\
\hline
\end{tabular}




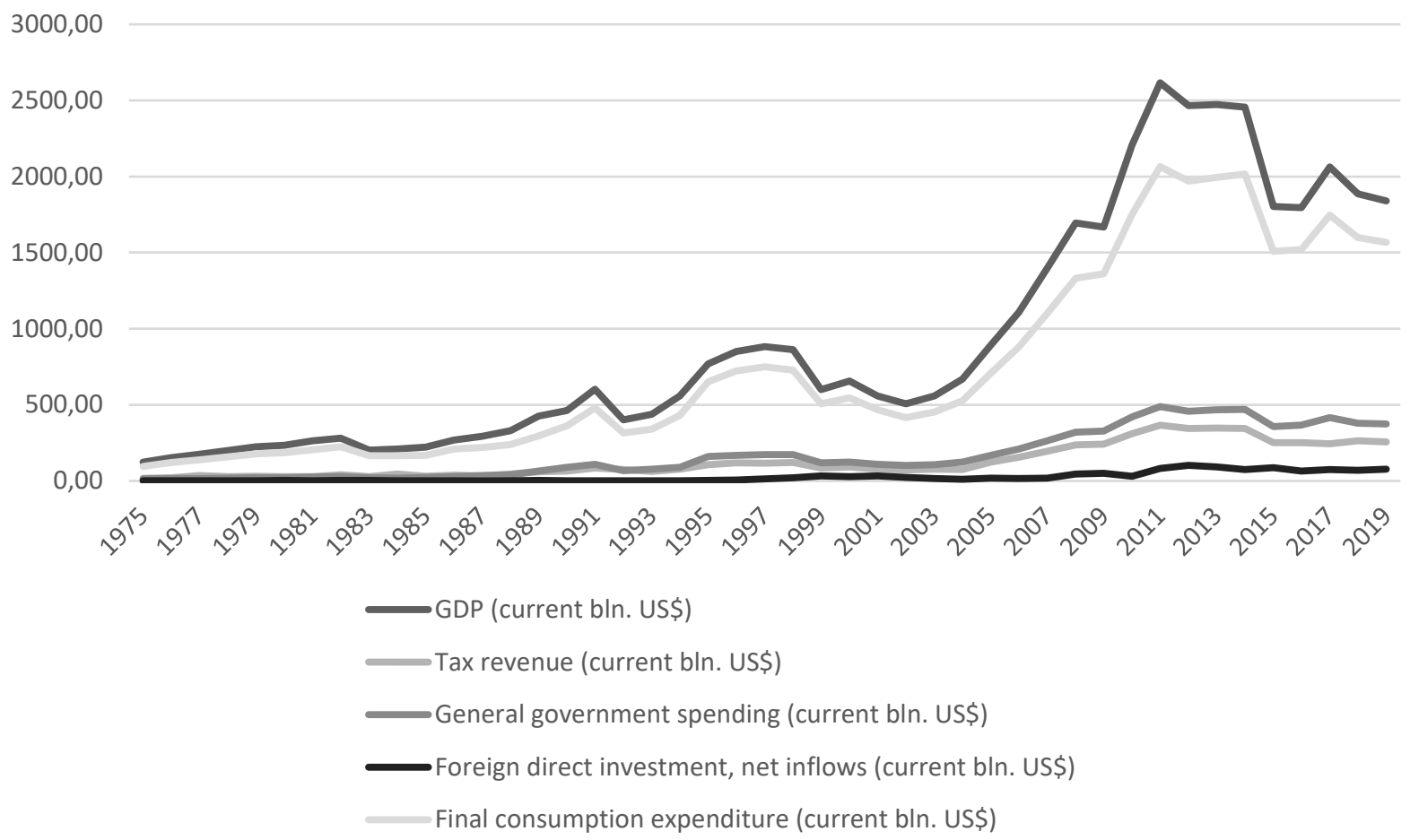

Picture 1. Dependence of variables on time

Table 2. Correlation matrix

\begin{tabular}{|l|c|c|c|c|c|c|}
\hline & $\begin{array}{c}\text { GDP } \\
\text { (current bln. } \\
\text { US\$) }\end{array}$ & $\begin{array}{c}\text { Tax revenue } \\
\text { (current bln. } \\
\text { US\$) }\end{array}$ & $\begin{array}{c}\text { General } \\
\text { government } \\
\text { spending } \\
\text { (current bln. } \\
\text { US\$) }\end{array}$ & $\begin{array}{c}\text { Foreign } \\
\text { direct } \\
\text { investment, } \\
\text { net inflows } \\
\text { (current bln. } \\
\text { US\$) }\end{array}$ & $\begin{array}{c}\text { Final con- } \\
\text { sumption } \\
\text { expenditure } \\
\text { (current bln. } \\
\text { US\$) }\end{array}$ & $\begin{array}{c}\text { R, Real } \\
\text { interest rate } \\
\text { (\%) }\end{array}$ \\
\hline GDP (current bln. US\$) & 1 & & & & & \\
\hline $\begin{array}{l}\text { Tax revenue (current } \\
\text { bln. US\$) }\end{array}$ & 0,9969 & 1 & & & & \\
\hline $\begin{array}{l}\text { General government } \\
\text { spending (current bln. } \\
\text { US\$) }\end{array}$ & 0,9973 & 0,9933 & 1 & & & \\
\hline $\begin{array}{l}\text { Foreign direct } \\
\text { investment, net } \\
\text { inflows (current bln. } \\
\text { US\$) }\end{array}$ & 0,9132 & 0,9092 & 0,9144 & 1 & \\
\hline $\begin{array}{l}\text { Final consumption } \\
\text { expenditure (current } \\
\text { bln. US\$) }\end{array}$ & 0,9989 & 0,9949 & 0,9988 & 0,9206 & 1 & \\
\hline $\begin{array}{l}\text { R, Real interest rate } \\
\text { (\%) }\end{array}$ & $-0,4067$ & $-0,4194$ & $-0,3908$ & $-0,2681$ & $-0,3944$ & \\
\hline
\end{tabular}




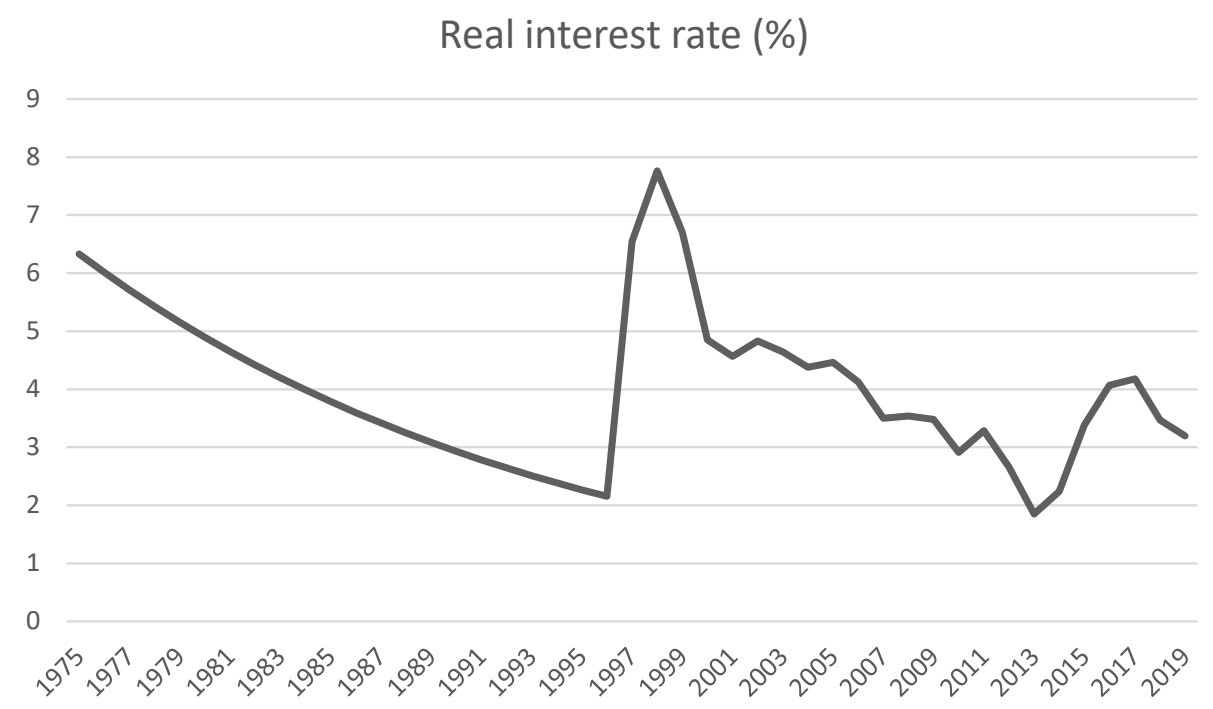

Picture 2. Dependence of interest rate on time [2]

\section{Final consumption expenditure (C)}

The usual least squares method allowed us to construct a model where the residuals are heteroscedastic, as indicated by the GoldfeldQuandt test, which does not satisfy the conditions of the Gauss-Markov theorem. For this reason, we applied the weighted least squares method.

Value of adjusted $\mathrm{R}$ square is quite high $(0,95)$ meaning that our leaner regression model describes $95 \%$ of all observations. P-value (F) $(2,53 \mathrm{e}-25)$ shows that quality of model is high and it could be used for some prediction of consumption. Having performed the Darbin-Watson test, we can note that this regression model does not have an autocorrelation of residuals.

Also based on p-value we can conclude that the coefficient GDP is significant on any level of significance. So, the regression model would have the following formula:

$$
C_{t}=39.4208+0.8034 \cdot Y_{t-1}+u_{t} \text {, }
$$

\section{Foreign direct investment (I)}

For the investment model we constructed the model based on ordinary least square method. But this leaner regression model couldn't be used because the coefficient before the parameter (GDPt-1-GDPt-2) is not significant on any level of significance $(a=0,01, a=0,05, a=0,10)$. By the way, according to the Darbin-Watson test, there is a negative autocorrelation. So this model can't be used.
Therefore, we created the new model (4) with modified parameters that include lagged interest rate, lagged GDP and current value of GDP. At this model we can see the high adjusted R square $(0,9421)$ that shows good quality of the description ability of the model.

$$
\begin{aligned}
& \mathrm{I}_{\mathrm{t}}=-24.3392+3.3323 \cdot \mathrm{R}_{\mathrm{t}-1} \\
& -0.0114 \cdot \mathrm{Y}_{\mathrm{t}}+0.0525 \cdot \mathrm{Y}_{\mathrm{t}-1}+\mathrm{v}_{\mathrm{t}},
\end{aligned}
$$

As for p-value of coefficient, we can admit all of them are significant on any level of significance, except the coefficient before GDP. Based on insignificance we should exclude it but it is stated in the model because the absence of it will cause the autocorrelation within the disturbance term.

General government final consumption expenditure $(G)$

For the government spending variable $(G)$ the model constructed with OLS and it suites all the conditions of GM theorem. The variable is significant $(6,42 \mathrm{e}-125<\mathrm{a}=0,01)$, adjusted $\mathrm{R}$ square is high and p-value (F) shows that the model is good.

$$
G_{t}=10.9105+0,9835 \cdot G_{t-1}+w_{t},
$$

Gross domestic product ( $Y$ )

The testing of the fourth regression model (GDP) shows the one insignificant coefficient that should excluded. But the missing of variable of government expenses will occurs autocorrelation and heteroscedasticity with disturbance term.

By the way, the value of adjusted R square and 
p-value (F) shows positive result of the testing (model has good description potential).

$$
\begin{aligned}
& Y_{t}=98.5796+0.6769 \cdot Y_{t-1} \\
& -0.2446 \cdot Y_{t-2}+2.6628 \cdot G_{t-1}+r_{t},
\end{aligned}
$$

Thus we can combine the information of the regression models within the table 3 . To evaluate the constructed models, we analyze the main indicators that can tell about the overall accuracy of the model [9].

Taking into account all the calculations with variables, we can construct the final model, including all regression linear models (Formula 7).

So, the considered Samuelson-Hicks model makes it possible to draw conclusions about the causes and factors of the occurrence of endogenous (self-generating) cyclical fluctuations in the economic system. Despite the abstract nature of the assumptions made in the models of oscillatory processes, it is impossible not to note the rigor and transparency of the conclusions obtained on the basis of the analysis.

We were able to identify the key variables that have a significant impact on the macroeconomic variables that characterize the Brazilian economy.

We can conclude that the model is quite good to describe our economic situation in Brazil. Based on the conducted analysis and obtained results, we can argue that the Samuelson-Hicks business cycle model corresponds to the realities of Brazil. This fact was proved by Durbin-Watson and Goldfield-Quant tests, which prove the Gauss-Markov theorem. The original purpose of such a system was to explain the existence of business cycles in an economy. The main assumption that the economy should be closed could be implied in the real world.

Table 3. Information about regression models

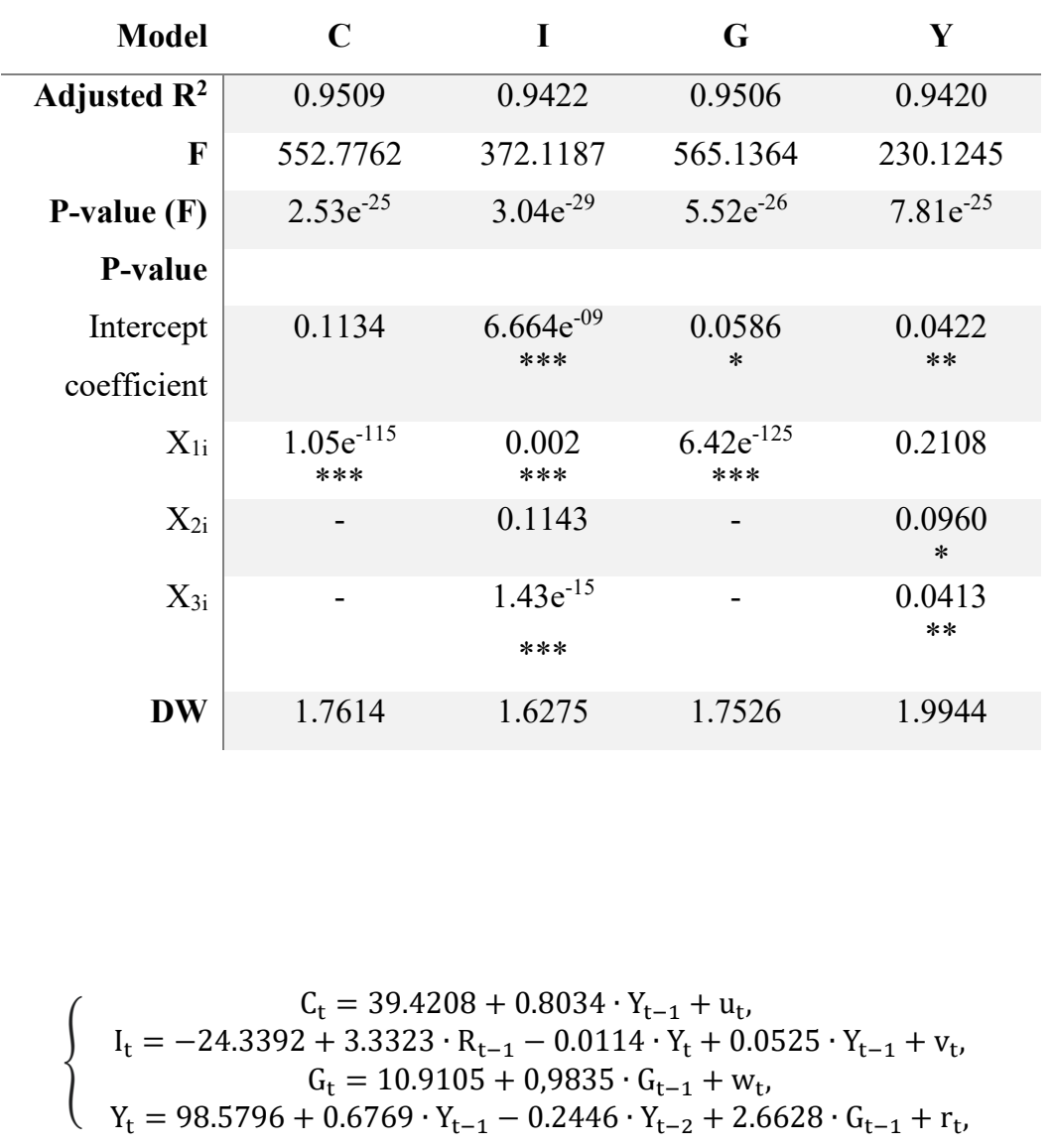




\section{References}

1. Barrueco E., Tregub I. V. Empirical verification of a hypothetical model on the German economy / Modern science. 2019. No. 3. pp. 36-41

2. Data of the national accounts of the World Bank [Electronic resource] - URL: https://data.worldbank.org/ (01.02.2021)

3. Prangishvili A. I., Obgadze L. T. Mathematical modeling of economic cycles and optimal management of capital investments / / Informatika i Telecommunications. 2005 No. 3 (7). p.: 59-61.

4. Samuelson P. A. Interaction of multiplicative analysis and the acceleration principle// Review of economic statistics. 1939, No. 4 p.: $75-78$,

5. Tregub I. V.Econometric analysis of the impact of monetary policy on macroeconomic aggregates in the Indian economy / / Journal of Physics: Conference Series. 8. Ser. «2018 8th International Conference on Applied Physics and Mathematics, ICAPM 2018» 2018.

6. Tregub I. V. Econometric research. Practical examples. Econometric research. Practical examples. - Moscow: Lan, 2017. $164 \mathrm{p}$.

7. Tregub I. V. Econometrica. Model of a real system. Moscow: 2016, $164 \mathrm{p}$.

8. Tregub I. V. Econometrics in English. Textbook. Moscow: 2017

9. Tregub I. V. Mathematical models of the dynamics of economic systems: monograph-Moscow: RUSAINS, 2018.$164 \mathrm{p}$. 